\title{
Kesiapan Individu Dan Organisasi Terhadap Komitmen Afektif Untuk Berubah Di Masa Pandemic Covid-19
}

\section{Individual and Organizational Readiness For Affective Commitments to Change In The Covid-19 Pandemic Era}

\author{
Dyan Angesti ${ }^{1}$, Muhadi ${ }^{2}$, Syanindita Prameswari ${ }^{3}$ \\ ${ }^{123}$ STIKES Yayasan Rumah Sakit Dr. Soetomo Surabaya \\ email: dyan_angesti@stikes-yrsds.ac.id muhadi@stikes-yrsds.ac.id \\ syaninditaprameswari99@gmail.com
}

\begin{abstract}
ABSTRAK
STIKES YRSDS sebagai salah satu perguruan tinggi swasta yang berkembang, kondisi pandemi COVID-19 ini merupakan hantaman luar biasa dan menjadi penentu apakah STIKES YRSDS mampu bertahan atau akan terhempas di era persaingan. Perubahan ini secara langsung akan berdampak pada mekanisme tata kelola yang ada. Tujuan penelitian yaitu menganalisis pengaruh kesiapan individu dan organisasi STIKES YRSDS terhadap komitmen afektif untuk berubah. Metode penelitian ini menggunakan teknik nonprobability sampling dengan metode convenience sampling. Subjek penelitian yaitu seluruh karyawan yang sudah menjadi tenaga tetap STIKES YRSDS sebanyak 44 orang. Hasil penelitian menunjukan kesiapan individu tidak berpengaruh signifikan terhadap komitmen afektif, uji variabel lain dalam penelitian menunjukkan bahwa kesiapan organisasi berpengaruh signifikan terhadap komitmen afektif, penelitian juga menunjukan Kesiapan Organisasi berpengaruh signifikan terhadap komitmen afektif. Hal ini menunjukan kesiapan organisasi memberikan pengaruh yang signifikan terhadap komitmen afektif karyawan STIKES YRSDS. Penelitian juga menunjukkan Kesiapan Individu dan Kesiapan Organisasi berpengaruh signifikan terhadap komitmen afektif karyawan STIKES YRSDS. Kesimpulan kesiapan individu karyawan tergolong tinggi dalam menghadapi perubahan di masa pandemic covid19, kesiapan organisasi tergolong sedang dalam menghadapi perubahan di masa pandemic covid19, ada pengaruh kesiapan organisasi terhadap komitmen afektif karyawan di masa pandemic covid19 dan tidak ada pengaruh antara kesiapan individu terhadap komitmen afektif karyawan STIKES YRSDS di masa pandemic covid19.
\end{abstract}

Kata Kunci: Kesiapan Individu, Kesiapan Organisasi, Komitmen Afektif

\begin{abstract}
STIKES YRSDS as one of the developing private universities that get tremendous affected due to COVID-19 pandemic. This will be determined whether STIKES YRSDS is able to survive in this competition era. This changes will directly impact to the existing governance mechanisms. The aims of this research is to analyze the effect of individual and organizational readiness of STIKES YRSDS on affective commitment to change. The research method used in this study is non-probability sampling technique with convenience sampling method. The research subjects are all 44 permanent staff of STIKES YRSDS. The results of this research showed that individual readiness had no significant effect on affective commitment, the test of other variables in the study showed that organizational readiness had a significant effect on affective commitment. It means that Organizational Readiness has a significant effect on the affective commitment of STIKES YRSDS employees. This research also showed that Individual Readiness and Organizational Readiness have a significant effect on the affective commitment of STIKES YRSDS employees. It can be concluded that Individual readiness employees is high in dealing with changes during the covid19 pandemic era. Meanwhile, organizational readiness is average to face the change in the covid19 pandemic era. There is an influence of organizational readiness on the affective commitment employees during the covid19 pandemic era and there is no influence between readiness individuals on the affective commitment of STIKES YRSDS employees during the covid19 pandemic era.
\end{abstract}

Keywords: Individual Readiness, Organizational Readiness, Affective Commitment 
Dyan Angesti, Muhadi, Syanindita Prameswari : Kesiapan Individu Dan Organisasi Terhadap ...

\section{PENDAHULUAN}

Sekolah Tinggi Ilmu Kesehatan (STIKES) Yayasan RS. Dr. Soetomo (YRSDS) merespon Kebijakan Khusus Pelaksanaan Tri Dharma Perguruan Tinggi serta Kebijakan Tatakelola Perguruan Tinggi STIKES YRSDS Selama Wabah Covid-19. Disisi lain tuntutan akan capaian lulusan dan kualitas pembelajaran serta layanan harus tetap dipertahankan sesuai dengan standar yang ada. Namun perubahan ini bukan hal yang mudah, berdasarkan hasil evaluasi semester genap TA 2019-2020, kepuasan mahasiswa akan pembelajaran daring dan layanan di STIKES YRSDS sebesar $<80 \%$ sedangkan standar kepuasan $>80 \%$. Sebagai salah satu perguruan tinggi swasta yang masih berkembang, kondsi pandemi COVID-19 ini merupakan hantaman yang luar biasa dan bisa menjadi penentu apakah STIKES YRSDS mampu bertahan atau akan terhempas di era persaingan yang ada. Perubahan cepat telah dilakukan salah satunya adalah perubahan struktur organisasi. Namun perubahan ini bukan hal yang mudah, berdasarkan hasil evaluasi semester genap TA 2019-2020 pembelajaran daring dan layanan di STIKES YRSDS sebesar $<80 \%$ sedangkan standar kepuasan $>80 \%$. Sehingga kepuasan mahasiswa kurang dari standart penjaminan mutu internal STIKES YRSDS. Oleh karena itu pengelola STIKES YRSDS berusaha merespon hasil evaluasi pembelajaran dengan perbaikan layanan, sarana prasarana, sampai dengan adanya perbaikan pada sistem pembelajaran secara daring. Tuntutan perubahan yang ada terjadi begitu cepat dan menuntut pengelola pendidikan tinggi untuk mengoptimalkan sumber daya yang dimilikinya.

Salah satu upaya yang dilakukan STIKES YRSDS adalah mengeluarkan kebijakan tata kelola berbasis teknologi sampai dengan perubahan struktur organisasi. Perubahan ini secara langsung akan berdampak pada mekanisme tata kelola yang ada. Situasi perubahan organisasi berdampak pada adanya paradigma baru dan lingkup perubahan menyasar ke seluruh bagian organisasi. Dengan adanya perubahan tersebut ditemukan tantangan, hambatan, dan kendala yang signifikan. Perubahan ini secara langsung akan berdampak pada mekanisme tata kelola yang ada. Situasi perubahan organisasi di STIKES YRSDS menurut Jick and Peiperl (2011) adalah perubahan yang bersifat transformasional. Hal ini dikarenakan perubahan yang terjadi bedampak pada adanya paradigma baru dan lingkup perubahan menyasar ke seluruh bagian organisasi. Dengan adanya perubahan tersebut ditemukan tantangan, hambatan, dan kendala yang signifikan. Melihat pentingnya faktor yakni kesiapan individu untuk berubah maupun kesiapan organisasi untuk berubah terhadap terciptanya komitmen afektif individu dalam mewujudkan keberhasilan 
perubahan organisasi menghadapi kebijakan tata kelola dan perubahan struktur organisasi, maka penelitian ini akan melihat bagaimana pengaruh kedua faktor tersebut terhadap komitmen afektif individu untuk berubah.

\section{METODE}

Penelitian ini menggunakan teknik non-probability sampling dengan metode convenience sampling. Subjek penelitian yaitu seluruh Karyawan yang sudah menjadi tenaga tetap STIKES YRSDS sebanyak 44 orang. Lokasi Penelitian ini yaitu di STIKES YRSDS terletak di Jln. Kalidami No. 14 Surabaya. Waktu pelaksanaan penelitian dilakukan pada April s/d Agustus 2021.

\section{HASIL}

Tabel 1 menggambarkan profile Karyawan STIKES YRSDS Surabaya sebanyak 44 responden menunjukkan bahwa karyawan yang berpartisipasi dalam survei ini adalah perempuan (52,27\%), usia 31-40 tahun yaitu (36,36\%). Pendidikan SDM tertinggi dari S2 $(47,73 \%)$ dan diikuti pendidikan D4/S1 $(31,82 \%)$. SDM yang ada jika dilihat dari Lama kerja tergolong lama dengan kisaran diatas 10 tahun yaitu $(38,64 \%)$ diikuti $<5$ tahun $(31,82 \%)$. Sebagai besar partisipan survei berasal dari koordinasi dan tanggungjawab wakil ketua 1 sebesar (50\%).

Tabel 1 Profil Karyawan STIKES Yayasan RS Dr.Soetomo (YRSDS) Surabaya

\begin{tabular}{lrrc}
\hline Karakteristik Individu & F & \% & $\begin{array}{c}\text { Komitmen Afektif } \\
\text { Sig. }\end{array}$ \\
\hline Jenis Kelamin & & & \\
$\quad$ Laki Laki & 21 & 47,73 & 0,785 \\
$\quad$ Perempuan & 23 & 52,27 & \\
\hline Usia & & & \\
20 - 30 Tahun & 11 & 25,00 & \\
31 - 40 Tahun & 16 & 36,36 & \\
40 - 50 Tahun & 5 & 11,36 & \\
$>$ 50 Tahun & 12 & 27,27 & \\
\hline Tingkat Pendidikan & & & \\
SLTA & 5 & 11,36 & \\
D1/D2/D3 & 4 & 9,09 & \\
D4/S1 & 14 & 31,82 & \\
S2 & 21 & 47,73 & \\
\hline
\end{tabular}

Lama Kerja 


\begin{tabular}{lccc}
\hline Karakteristik Individu & F & $\%$ & $\begin{array}{c}\text { Komitmen Afektif } \\
\text { Sig. }\end{array}$ \\
\hline$\quad$ < Tahun & 14 & 31,82 & 0,01 \\
$\quad$ 5 - 10 Tahun & 13 & 29,55 & \\
$\quad>10$ Tahun & 17 & 38,64 & \\
Koordinasi Waket & & & \\
\hline $\begin{array}{l}\text { Waket 1 (dibawah koordinasi dan } \\
\text { tanggung jawab) }\end{array}$ & 22 & 50,00 & \\
$\begin{array}{l}\text { Waket 2 (dibawah koordinasi dan } \\
\text { tanggung jawab) }\end{array}$ & 13 & 29,55 & 0,352 \\
$\begin{array}{l}\text { Waket 3 (dibawah koordinasi dan } \\
\text { tanggung jawab) }\end{array}$ & 9 & 20,45 & \\
\hline
\end{tabular}

Penelitian ini melibatkan 44 partisipan yaitu mengukur kesiapan individu, kesiapan organisasi, komitmen afektif untuk berubah dan menguji hipotesa pengaruh kesiapan individu dan organisasi terhadap komitmen afektif untuk berubah. Dalam penelitian ini menggunakan skala pengukuran 1 sampai 4 mulai dari sangat tidak setuju, tidak setuju, setuju dan sangat setuju. Data penelitian dianalisis menggunakan statistik deskriptif, dan simple regression. Berdasarkan hasil uji statistik deskriptif yang dilakukan, terdapat temuan bahwa usia dan lama kerja individu memiliki hubungan positif dan signifikan dengan Komitmen Afektif untuk berubah $(\mathrm{p}<0.05)$. Semakin lama usia dan lama kerja karyawan semakin menunjukan komitmen afektif untuk berubah.

\section{Kesiapan individu untuk berubah}

Kesiapan Individu terdiri dari 4 dimensi yaitu kesesuaian, dukungan manajemen, kepercayaan terhadap kemampuan pribadi, manfaat perubahan bagi individu. Total pertanyaan yang mewakili kesiapan individu untuk berubah sejumlah 20 item pertanyaan. Berikut ini adalah kategori tingkat kesipan individu untuk berubah:

Tabel 2 Tingkat Kesiapan Individu Untuk Berubah di STIKES YRSDS Surabaya

\begin{tabular}{ccc}
\hline Tingkat Kesiapan Individu & f & \% \\
\hline Rendah & 13 & 29,55 \\
Tinggi & 31 & 70,49 \\
& 44 & 100 \\
\hline
\end{tabular}

Dimensi ini menjelaskan tentang aspek keyakinan individu bahwa perubahan yang diajukan akan tepat bagi organisasi dan organisasi akan mendapat keuntungan dari penerapan perubahan. Individu akan meyakini adanya alasan yang logis untuk berubah dan adanya kebutuhan untuk berubah yang diusulkan, serta berfokus pada manfaat dari perubahan bagi perusahaan, efisiensi yang diperoleh dari perubahan dan kongruensi 
tujuan perusahaan dengan tujuan perubahan. Berdasarkan tabel diatas didapatkan data bahwa $61,36 \%$ meyakini kesesuaian perubahan yang ada. Sebanyak $70,49 \%$ dinilai kesiapan individu tergolong tinggi dan sebanyak $29,55 \%$ tergolong sedang.

\section{Tabel 3 Dimensi Kesiapan Individu Untuk Berubah di STIKES YRSDS Surabaya}

\begin{tabular}{lc}
\multicolumn{1}{c}{ Variabel } & Kategori \\
\hline Kesiapan Individu & Tinggi \\
Kesesuaian perubahan & Tinggi \\
Dukungan manajemen & Tinggi \\
Kepercayaan terhadap kemampuan pribadi & Sedang \\
Manfaat perubahan bagi individu & \\
\hline
\end{tabular}

Berdasarkan data table diatas, Variabel X1 dengan 4 dimensinya menunjukkan kesiapan Individu masuk dalam kategori Tinggi. Dimensi kesiapan individu yaitu Management support (dukungan manajemen) dimensi ini menjelaskan aspek keyakinan atau persepsi individu bahwa para pemimpin atau manajemen akan mendukung dan berkomitmen terhadap perubahan yang diusulkan. Ketika organisasi memberikan dukungan kepada karyawan, maka karyawan pun akan siap memberikan dukungan kepada organisasi, salah satunya adalah siap mendukung perubahan terutama pada kondisi pandemi saat ini. Karyawan meyakini mendapatkan dukungan dari pihak manajemen melalui komunikasi dan dukungan kebijakan. Change specifik efficacy (rasa percaya terhadap kemampuan untuk berubah) dimensi ini menjelaskan aspek keyakinan individu tentang kemampuannya untuk menerapkan perubahan yang diinginkan oleh pimpinan.

Individu merasa mempunyai keterampilan serta sanggup untuk menyelesaikan tugas dan aktivitas yang berkaitan dengan pelaksanaan perubahan yang diusulkan. Dimensi ini juga menjelaskan tentang tingkat kepercayaan diri individu untuk dapat mensukseskan perubahan yang direncanakan. Karyawan meyakini mendapatkan dukungan dari pihak manajemen pada setiap gagasan atau ide untuk merencanakan perubahan. Personal valance (manfaat bagi individu) dimensi ini menjelaskan aspek keyakinan mengenai keuntungan yang dirasakan secara personal yang akan didapatkan apabila perubahan tersebut diimplementasikan. Dengan begitu, karyawan merasa bahwa ia akan memperoleh manfaat dari pelaksanaan perubahan yang diusulkan. Karyawan meyakini mendapatkan dukungan dari pihak manajemen. Nilai tertinggi ditunjukan dengan dukungan manajemen dan kepercayaan terhadap kemampuan pribadi. 
Dyan Angesti, Muhadi, Syanindita Prameswari : Kesiapan Individu Dan Organisasi Terhadap ...

\section{Kesiapan Organisasi untuk Berubah}

Kesiapan Organisasi terdiri dari 3 dimensi yaitu tuntutan tugas, faktor konsektual yang memungkinkan, persepsi terhadap sumber daya organisasi dan faktor situasional. Dimensi tuntutan tugas dengan 4 pertanyaan, faktor konsektual yang memungkinkan dengan 10 pertanyaan, persepsi terhadap sumber daya organisasi dan faktor situasional dengan 6 pertanyaan dan komitmen afektif untuk berubah terdapat 4 pertanyaan.

Tabel 4 Tingkat Kesiapan Organisasi untuk Berubah di STIKES YRSDS Surabaya

\begin{tabular}{ccc}
\hline Tingkat Kesiapan Organisasi & f & \% \\
\hline Sedang & 15 & 34,09 \\
Tinggi & 29 & 65,91 \\
& 44 & 100 \\
\hline
\end{tabular}

Kesiapan Organisasi ada 4 dimensi yaitu tuntutan tugas dengan 4 pertanyaan, faktor konsektual yang memungkinkan dengan 10 pertanyaan, persepsi terhadap sumber daya organisasi dan faktor situasional dengan 6 pertanyaan. Dimensi ini menjelaskan Kesiapan organisasi menghadapi tuntutan intenral dan kesiapan organisasi menghadapi tuntutan eksternal. Sebanyak 65,91\% menilai tinggi sedangkan 34,09\% menilai sedang.

Tabel 5 Dimensi Kesiapan Organisasi untuk Berubah di STIKES Yayasan RS Dr.Soetomo Surabaya

\begin{tabular}{cc}
\hline \multicolumn{1}{c}{ Variabel } & Kategori \\
\hline Kesiapan organisasi & \\
\hline Tuntutan tugas & Tinggi \\
Faktor kontekstual yang memungkinkan & Tinggi \\
Persepsi terhadap sumber daya organisasi & Sedang \\
Faktor situasional & Sedang \\
\hline
\end{tabular}

Tuntutan tugas mencakup kemampuan karyawan menyelesaikan deadline tugas dari pimpinan, mendukung kebijakan dan prosedur organisasi, kemampuan mencapai tujuan secara internal tergolong tinggi sedangkan persepi terhadap sumber daya organisasi dan faktor situasional tergolong sedang. Analisis regresi bertujuan untuk mengetahui pengaruh variabel yang di analisis. Koefisien determinasi bertujuan untuk mengukur kontribusi variabel bebas (Kesiapan Indvidu (X1), Kesiapan Organisasi (X2) terhadap Komitmen Afektif atau variabel terikat (Y). Baik koefisien korelasi dan determinasi dapat diuji secara parsial maupun simultan. Parsial berarti analisis variabel bebas (secara sendiri-sendiri) dikaitkan dengan variabel $\mathrm{Y}$, sedangkan simultan berarti variabelbebas (secara bersama-sama) dikaitkan dengan variabel Y. 
Tabel 6 Analisis Regresi Kesiapan Individu dan Organisasi terhadap Komitmen Afektif di STIKES YRSDS Surabaya

\begin{tabular}{lc}
\hline Variabel & Sig. \\
\hline Komitmen Afektif & 0,526 \\
Kesiapan Individu & 0,886 \\
Kesiapan Organisasi & 0,003 \\
\hline
\end{tabular}

Berdasarakan hasil uji statistik menggunakan model regresi linear faktor kesiapan Individu (X1) tidak berpengaruh secara signifikan terhadap komitmen afektif (Y) karyawan di STIKES YRSDS. Faktor Kesiapan Organisasi (X2) berpengaruh secara signifikan terhadap komitmen afektif (Y) karyawan STIKES YRSDS. Kesiapan Individu (X1) tidak mempunyai pengaruh yang signifikan terhadap komitmen afektif (Y) karyawan di STIKES YRSDS. Dari pengujian yang dilakukan bahwa thitung sebesar 0,145 dengan tingkat signifikasi sebesar 0,886 . Oleh karena tingkat signifikasi ini lebih besar dari 0,05 maka tidak ada pengaruh yang signifikan variabel kesiapan individu terhadap komitmen afektif karyawan STIKES YRSDS. Dari hasil tersebut maka hipotesis disimpulkan belum terbukti (belum diterima kebenarannya).

Kesiapan Organisasi (X2) mempunyai pengaruh yang signifikan terhadap komitmen afektif (Y) karyawan di STIKES YRSDS. Dari pengujian yang dilakukan bahwa thitung sebesar 3,128 dengan tingkat signifikasi sebesar 0,003. Oleh karena tingkat signifikasi ini lebih kecil dari 0,05 maka ada pengaruh yang signifikan variabel kesiapan organisasi terhadap komitmen afektif karyawan STIKES YRSDS. Dari hasil tersebut maka hipotesis disimpulkan terbukti (diterima kebenarannya).

\section{PEMBAHASAN}

Holt, et al. (2007) mendefinisikan kesiapan individu untuk berubah sebagai sikap komprehensif yang secara simultan dipengaruhi oleh isi (apa yang berubah), proses (bagaimana perubahan diimplementasikan), konteks (lingkungan dimana perubahan terjadi), dan individu (karakteristik individu yang diminta untuk berubah) yang terlibat di dalam suatu perubahan. Armenakis, et al. (1993) dan Anderson (2002) menyatakan bahwa kesiapan pekerja adalah prekursor kognitif perilaku yang mendukung upaya perubahan dan tercermin dalam kesediaan anggota organisasi untuk mengadopsi perubahan (Mangundjaya, 2016). Kesiapan berubah meliputi kesiapan secara mental, psikologi, maupun fisik siap atau prima untuk berpartisipasi dalam kegiatan pengembangan organisasi. 
Dyan Angesti, Muhadi, Syanindita Prameswari : Kesiapan Individu Dan Organisasi Terhadap ...

Kesiapan organisasi untuk berubah merupakan kebersamaan tekad anggota organisasi untuk mengimplementasikan perubahan (komitmen perubahan) dan kepercayaan bersama pada kemampuan kolektif yang mereka miliki dalam melakukan perubahan tersebut (Weiner, 2009). Komitmen afektif merupakan salah satu kategori komitmen menurut Meyer et al. (2002) yang mana komitmen ini merupakan ikatan secara emosional yang melekat pada seorang karyawan untuk mengidentifikasikan dan melibatkan dirinya dengan organisasi. Komitmen afektif ini juga dapat dikatakan sebagai penentu yang penting atas dedikasi dan loyalitas seorang karyawan.

Hasil dalam penelitian ini menunjukan bahwa Kesiapan Individu tidak berpengaruh secara signifikan terhadap komitmen afektif karyawan STIKES YRSDS dengan t hitung sebesar 0,145. Hal ini berarti bahwa Kesiapan Individu terdiri dari kesesuaian perubahan, dukungan manajemen, kepercayaan terhadap kemampuan pribadi, manfaat perubahan bagi individu belum memberikan pengaruh yang signifikan terhadap komitmen afektif karyawan STIKES YRSDS. Namun hasil uji variabel lain dalam penelitian menunjukan bahwa kesiapan organisasi berpengaruh secara signifikan terhadap komitmen afektif karyawan STIKES YRSDS dengan thitung sebesar 3,128. Hal ini mengartikan bahwa kesiapan organisasiyang terdiri dari tuntutan tugas, faktor konsektual yang memungkinkan, persepsi terhadap sumber daya organisasi dan faktor situasional memberikan pengaruh signifikasi terhadap kinerja karyawan pada komitmen afektif karyawan STIKES YRSDS. Dan hasil dalam penelitian ini juga menunjukan bahwa kesiapan organisasi berpengaruh secara signifikan terhadap komitmen afektif karyawan STIKES YRSDS dengan thitung 4,048. Hal ini berarti bahwa kesiapan organisasi memberikan pengaruh yang signifikasi terhadap komitmen afektif karyawan STIKES YRSDS.

Selanjutnya hasil penelitian ini juga menunjukan bahwa kesiapan Individu dan kesiapan organisasi berpengaruh secara signifikan (hubungan yang parsial) terhadap komitmen afektif karyawan STIKES YRSDS dengan F hitung 11,803. nilai koefisien determinasi $\left(\mathrm{R}^{2}\right) / \mathrm{R}$ squer sebesar 0,604 mempunyai arti variasi seluruh variabel bebas dapat mempengaruhi perubahan Variabel Terikat sebesar 0,604 (60,4\%). Sedangkan sisanya 39,6\% dipengaruhi oleh variabel lain diluar penelitian.

Hal ini masih sejalan dengan hasil penelitian Harimurti \& Mariatin (2014) analisa data menunjukkan pengaruh positif dan signifikan dari variabel kesiapan berubah, komitmen terhadap organisasi, dan komunikasi tentang perubahan organisasi, terhadap penerapan performance management system. Demikian juga penelitian yang dilakukan 
Hasil penelitian Zebua (2018) menunjukkan ada pengaruh positif yang signifikan antara komitmen organisasi dengan kesiapan untuk berubah terutama pada komitmen afektif dan normatif. Namun Hal ini tidak sejalan dengan penelitian Guamaradewi \& L. Mangundjaya (2018) menunjukkan bahwa kesiapan individu untuk berubah dan kesiapan organisasi untuk berubah berpengaruh positif dan signifikan bagi komitmen afektif untuk berubah. Lebih lanjut, hasil penelitian menunjukkan kesiapan individu untuk berubah memiliki pengaruh yang lebih besar dibandingkan kesiapan organisasi untuk berubah. Selain itu, penelitian juga menunjukkan terdapat hubungan yang positif dan signifikan antara usia dan pengalaman kerja bagi kesiapan individu untuk berubah.

Hasil penelitian ini tidak sejalan dengan Astuti \& Muftia (2018) yang menunjukkan tidak adanya pengaruh employee engagement terhadap kesiapan untuk berubah karyawan Universitas Ahmad Dahlan dengan nilai signifikansi sebesar 0,244 > 0,05 serta adanya pengaruh komitmen organisasi terhadap kesiapan untuk berubah (readiness for change) karyawan Universitas Ahmad Dahlan. Hasil penelitian Andriyanto \& Haerudin (2018) menunjukkan bahwa komitmen organisasi berpengaruh positif terhadap sikap karyawan pada perubahan hanya pada dimensi afektif saja, sedangkan pada dimensi kognitif dan behavioral tidak berpengaruh. Selain itu hasil penelitian menunjukkan bahwa komitmen organisasi memiliki hubungan yang kuat dengan kesiapan individu untuk berubah. Komitmen merupakan salah satu faktor terpenting yang melandasi keterlibatan karyawan dalam mendukung inisiatif perubahan. Faktor yang mengakibatkan usaha perubahan mengalami kegagalan adalah disebabkan adanya kesenjangan antara komitmen individual dan organisasi.

Penelitian ini sejalan dengan Prastiti (2021) yang menyatakan komitmen organisasi memiliki hubungan positif dan signifikan dengan kesiapan untuk berubah. Ini berarti bahwa ketika variabel komitmen organisasi meningkat, nilai kesiapan untuk mengubah kondisi dan sebaliknya. Peningkatan komitmen organisasi menyebabkan peningkatan kesiapan karyawan untuk berubah. Penelitian ini menunjukkan bahwa kesiapan variabel untuk berubah dipengaruhi oleh komitmen organisasi, yang berjumlah $73,3 \%$, sementara faktor-faktor lain mempengaruhi 26,7\%. Hal yang berbeda didapat pada Barawati, et al. (2018) berdasarkan uji hipotesis didapatkan bahwa nilai sig komitmen afektif lebih kecil dari 0,05 yaitu 0,021. Hal ini menunjukkan bahwa terdapat pengaruh antara komitmen afektif terhadap change self efficacy karyawan PT. Kayan Putra Utama Coal dimana 5,2\% change self efficacy karyawan dipengaruhi oleh komitmen afektif yang ada pada karyawan PT. Kayan Putra 
Dyan Angesti, Muhadi, Syanindita Prameswari : Kesiapan Individu Dan Organisasi Terhadap ...

Utama Coal yang berarti bahwa 94,8\% kesiapan untuk berubah karyawan PT. Kayan Putra Utama Coal dipengaruhi oleh faktor lain yang tidak dimasukan dalam penelitian ini.

Pada penelitian Mujiburrahman, et. al (2017) tentang pengaruh komitmen afektif terhadap kesiapan untuk berubah pegawai Puskesmas Kabupaten Lombok Barat. Membuktikan bahwa komitmen afektif berpengaruh signifikan terhadap kesiapan untuk berubah karyawan Puskesmas Kabupaten Lombok Barat. Pegawai yang mempunyai komitmen tinggi terhadap organisasi akan memberikan pemikiran dan tenaganya untuk organisasi. Kemajuan organisasi adalah kemajuan pegawai. Masalah organisasi adalah masalah pegawai. Pegawai menerima nilai-nilai tujuan organisasi dan pegawai mendukung perkembangan organisasi serta pegawaipun siap dalam menghadapi perubahan di organisasi.

STIKES YRSDS sebagai sebuah entitas sosial yang terdiri dari berbagai macam individu harus dapat mengelola perubahan dengan baik, untuk itu dukungan komitmen pimpinan sangat penting, sehingga dapat mempertahankan kelangsungan hidup dan pengembangan organisasi. Perubahan merupakan salah satu proses yang dapat membawa organisasi untuk mencapai tujuannya, sehingga pimpinan yang memiliki komitmen terhadap organisasi akan berpartisipasi secara aktif dalam menghadapi perubahan agar dapat mencapai tujuan organisasi. Pimpinan dalam hal ini adalah pihak manajemen STIKES YRSDS harus sensitif dan solutif dalam merespon perubahan dan tuntutan terhadap perubahan serta memberi perhatian khusus dan melakukan beberapa upaya untuk mempertahankan dan meningkatkan serta menumbuhkan komitmen organisasi pada karyawan STIKES YRSDS karena untuk kedepannya STIKES YRSDS akan menghadapi banyak perubahan dan tantangan.

Upaya peningkatan kesiapan individu dapat melalui pemberdayaan karyawan secara lebih aktif dalam mengimplementasikan perubahan. Diharapkan dengan hal tersebut karyawan akan memiliki tingkat partisipasi dan keterlibatan yang tinggi dalam proses perubahan. Secara tidak langsung hal ini akan meningkatkan motivasi dan loyalitas karyawan terhadap organisasi. Namun perlu diperhatikan adanya pembagian beban kerja diantara karyawan, dengan harapan seluruh karyawan mampu berperan aktif bukan hanya beberapa karyawan yang terlibat secara aktif dan mampu beradaptasi dengan perubahan organisasi. Oleh karena itu pihak manajemen perlu juga mengadakan pelatihan khusus secara proaktif yang bertujuan untuk mendidik dan membentuk kapasitas mental yang kuat bagi karyawan sehingga siap menghadapi perubahan dengan baik. 


\section{SIMPULAN}

Berdasarkan pada hasil analisis dan pengujian hipotesis, dapat ditarik beberapa kesimpulan sebagai berikut yaitu usia dan lama bekerja berpengaruh positif terhadap komitmen afektif karyawan STIKES YRSDS dimasa pandemi covid19. Kesiapan indvidu karyawan STIKES YRSDS tergolong tinggi dalam menghadapi perubahan di masa pandemic covid19. Kesiapan organisasi STIKES YRSDS tergolong sedang dalam menghadapi perubahan di masa pandemic covid19. Ada pengaruh kesiapan organisasi terhadap komitmen afektif karyawan STIKES YRSDS di masa pandemic covid19. Tidak ada pengaruh antara kesiapan individu terhadap komitmen afektif karyawan STIKES YRSDS di masa pandemic covid19.

\section{UCAPAN TERIMA KASIH}

Pada kesempatan ini peniliti ingin mengucapkan terimakasih kepada Direktorat Riset dan Pengabdian Masyarakat Kemendikbud (DRPM) dan Ketua STIKES Yayasan RS. Dr. Soetomo, Ketua Program Studi S1 Administrasi Rumah Sakit dan semua pihak yang terlibat dalam membantu, memberikan saran dan masaukan pada penelitian ini.

\section{DAFTAR PUSTAKA}

Anderson, B. (2002). Readiness for change: An individual perspective (Issue October). Jamaica: Northern Carribean University, Business Administration.

Andriyanto, I., \& Haerudin, H. (2018). Peran Komitmen Organisasi Sebagai Mediator Pengaruh Etika Kerja Islam Terhadap Sikap Pada Perubahan. El Dinar, 5(1), 17. https://doi.org/10.18860/ed.v5i1.5232

Armenakis, A.A., Harris, S.G., Massgolder, K. W. (1993). Creating Readiness for Organizational Change". Human Relations Journal. Human Relations Journal, 46, 681-703.

Astuti, M. \&. (2018). Berubah ( Readiness for Change ) Pada Karyawan. 8(2012), 4766.

Barawati, E., Umaroh, S. K., \& Imawati, D. (2018). Kesiapan Untuk Berubah Karyawan Survivors Komitmen Afektif Sebagai Mediator Readiness To Change Employees Survivors Pt . Kayan Putra Utama Coal Reviewed From Psychological Climate With Afective Commitments As Mediators. 1(2), 1-9.

Guamaradewi, N. G., \& L. Mangundjaya, W. (2018). Dampak Kesiapan Individu dan Kesiapan Organisasi untuk Berubah bagi Komitmen Afektif untuk Berubah. Jurnal Manejemen Aset Infrastruktur \& Fasilitas, 2(2). https://doi.org/10.12962/j26151847.v2i2.4340

Harimurti, E., \& Mariatin, E. (2014). Pengaruh Kesiapan Berubah, Komitmen Terhadap Organisasi Dan Komunikasi Tentang Perubahan Organisasi Terhadap Penerapan Performance Management System. Jurnal Analitika, 6(1), 27-36.

Holt, D. T., Armenakis, A. A., Harris, S. G., \& Feild, H. S. (2007). Toward a Comprehensive Definition of Readiness for Change: A Review of Research and 
Instrumentation. In W. A. Pasmore \& R. W. Woodman (Eds.), Research in Organizational Change and Development (Vol. 16, pp. 289-336). Emerald Group Publishing Limited. https://doi.org/10.1016/S0897-3016(06)16009-7

Jick, T.D \& Peiperl, M. . (2011). Managing Change, cases dan concepts (3rded ed.). McGraw-Hill/Irwin.

Mangundjaya, W. L. (2016). Psikologi dalam perubahan organisasitle. Swasthi Adi Cita Publishing Indonesia.

Meyer, J. P., Stanley, D. J., Herscovitch, L., \& Topolnytsky, L. (2002). Affective, continuance, and normative commitment to the organization: A meta-analysis of antecedents, correlates, and consequences. Journal of Vocational Behavior, 61(1), 20-52. https://doi.org/10.1006/jvbe.2001.1842

Mujiburrahman, M. (2017). Pengaruh Kepemimpinan Transformasional Dan Iklim Psikologis Terhadap Kesiapan Untuk Berubah Karyawan Puskesmas Kabupaten Lombok Barat Dalam Rangka Akreditasi Dan Komitmen Afektif Sebagai Variabel Intervening. Jmm Unram - Master of Management Journal, 6(2), 1-19. https://doi.org/10.29303/jmm.v6i2.106

Prastiti, Z. D. (2021). The Relationship Between Organizational Commitment and Readiness to Change for Employee of PT X. Jurnal Organisasi Dan Manajemen, 17(1), 78-88. https://doi.org/10.33830/jom.v17i1.1003.2021

Weiner, B. J. (2009). A theory of organizational readiness for change. Implementation Science, 4(67), 1-9. https://doi.org/10.1186/1748-5908-4-67

Zebua. (2018). Hubungan antara komitmen organisasi dengan kesiapan berubah pada karyawan pt. toyota astra financial services, jakarta selatan.

\begin{tabular}{|l|l|}
\hline Submission & $29-09-2021$ \\
\hline Review & $08-10-2021$ \\
\hline Accepted & $13-10-2021$ \\
\hline Publish & $29-10-2021$ \\
\hline DOI & 10.29241 jmk.v7i2.837 \\
\hline Sinta Level & 3 (Tiga) \\
\hline
\end{tabular}

